\title{
Familial Mediterranean Fever associated diseases in children
}

\author{
ZB Özçakar ${ }^{1 *}$, N Cakar $^{2}$, N Uncu², B Acar Celikel², F Yalçınkaya ${ }^{1}$ \\ From 8th International Congress of Familial Mediterranean Fever and Systemic Autoinflammatory Diseases \\ Dresden, Germany. 30 September - 3 October 2015
}

\section{Question}

Familial Mediterranean fever (FMF) is an autosomal recessive disease, characterised by recurrent, self limited attacks of fever with serositis. Certain diseases were more commonly detected in patients with FMF. The aim of our study was to investigate the frequency of FMF-associated diseases in children.

\section{Methods}

Files of FMF patients who had been seen in two reference hospitals in Ankara, in the last two years, were retrospectively evaluated. Patients with FMF and concomitant diseases were incuded to the study.

\section{Results}

Among 600 FMF patients 30 (18 females, 12 males; mean age 14,72 \pm 5.47 years) of them (5\%) were found to have a concomitant disease. Fourteen patients had juvenile idiopathic artritis; 5 had sacroilitis (3 of them had HLA B27 positivity); 6 had inflammatory bowel disease and 5 had other diseases including a patient with Behçet's disease and one with systemic lupus erythematosus. Mean age at FMF onset and associated disease onset were 54,00 \pm 46,35 months and 90,46 $\pm 51,65$ months, respectively. $52 \%$ of the patients had homozygous M694V mutation. Classical FMF attacks were present in 26 patients; remaining 4 patients had atypical symptoms but had 2 mutations.

\section{Conclusions}

Certain inflammatory diseases were more frequently detected in patients with FMF during childhood. In countries where FMF is prevalent clinicians dealing with FMF and other inflammatory diseases should be aware of these associations.

${ }^{1}$ Ankara University, Pediatric Rheumatology, Ankara, Turkey

Full list of author information is available at the end of the article
Authors' details

${ }^{1}$ Ankara University, Pediatric Rheumatology, Ankara, Turkey. ${ }^{2}$ Ankara Child Health, Hematology, Oncology Education and Research Hospital, Pediatric Rheumatology, Ankara, Turkey.

Published: 28 September 2015

doi:10.1186/1546-0096-13-S1-P84

Cite this article as: Özçakar et al:: Familial Mediterranean Fever associated diseases in children. Pediatric Rheumatology 2015 13(Suppl 1): P84.
Submit your next manuscript to BioMed Central and take full advantage of:

- Convenient online submission

- Thorough peer review

- No space constraints or color figure charges

- Immediate publication on acceptance

- Inclusion in PubMed, CAS, Scopus and Google Scholar

- Research which is freely available for redistribution
() Biomed Central

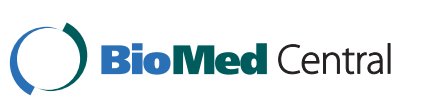

(c) 2015 Özçakar et al. This is an Open Access article distributed under the terms of the Creative Commons Attribution License (http:// creativecommons.org/licenses/by/4.0), which permits unrestricted use, distribution, and reproduction in any medium, provided the original work is properly cited. The Creative Commons Public Domain Dedication waiver (http://creativecommons.org/publicdomain/ zero/1.0/) applies to the data made available in this article, unless otherwise stated. 